\title{
The COVID-19 Pandemic and Community's New Habits
}

\author{
Roslinawati* \\ Department of Sociology, Faculty of Social and Political Sciences, Tadulako University, Indonesia \\ *Coresponding Author \\ Email : roslinawati.ap@gmail.com
}

\begin{abstract}
COVID-19 or coronavirus disease is transmitted from human to human and its spread is getting wider along with human mobility. The wider spread has made various countries implement various policies to stop the spread of the virus. This study aims to determine the impact of the COVID-19 pandemic and the community's new habits. This study was conducted in Palu City. It used a qualitative approach. The instrument of the study was the researcher with the help of interview guides. The data analysis consisted of data reduction, data presentation, and conclusion drawing. The results of this study showed that COVID-19 has had a major impact on human life and even created new habits in the community.
\end{abstract}

Keywords: pandemic, change, behavior, habit, community, new habit

\section{INTRODUCTION}

The biggest challenge of this century is a humanitarian tragedy such as COVID-19 (Latief, Hasbi, \& Amandaria, 2021). The rapid spread of the virus is caused by human activities (Tatem, Rogers, \& Hay, 2006; Wilson, 1995). The government responded to the spread of this virus by implementing various non-pharmaceutical policies that were considered effective in stopping the spread of the virus (Basellini et al., 2020; Brauner et al., 2021) to control the pandemic (Brauner et al., 2021).

The COVID-19 pandemic has spread throughout the world disrupting all community activities. It was caused by the implementation of government policies considered effective in stopping the spread of the virus. In Indonesia, the government has implemented some policies concerning the COVID-19, such as Large-Scale Social Restrictions (PSBB) and the Public Activity Restrictions (PPKM).

The Large-Scale Social Restrictions policy was implemented in 2020, while in 2021 the government of Indonesia has consisted implemented the Public Activity Restriction Policy. The implementation of the policy aims to stop the spread of the virus, but the policy has also disrupted the community social activities such as the limitation of office and community activities. As a result, the community has new habits in everyday life. Indirectly, government policies also have an impact on people's social behavior.

The social behavior of the people in Palu City has changed too. Previously, people do activities without wearing masks, gathering and socializing, working in offices, attend face-toface school meetings, and others, but then everything has changed after the pandemic occurred. People have new habits. Thus, this study aims to identify the impact of the COVID-19 pandemic and the new habits of the people in Palu City. 


\section{RESEARCH METHODS}

This study used a qualitative approach. Qualitative is a type of study that examines social phenomena broadly about people's lives, individual and group behavior, and interactions that result in relationships (Teherani, Martimianakis, Stenfors-Hayes, Wadhwa, \& Varpio, 2015). The population of this study was the people of Palu City, Central Sulawesi Province, Indonesia. The sample was taken from some sub-districts (West Palu, East Palu, North Palu, South Palu, Tatanga, Ulujadi, Mantikulore, and Tawaeli sub-districts) in which each sub-district was represented by 1 respondent so that there were 8 respondents.

Data were collected by field observations, in-depth interviews, and documentation. Then, the data were analyzed using data reduction, data presentation, and conclusion drawing. In qualitative data analysis techniques, the researcher becomes the main instrument in the study. So, the instrument of this study was the researcher (Teherani et al., 2015).

\section{RESULTS AND DISCUSSION}

COVID-19 pandemic affects human activities and it has become a challenge for the world as the virus is transmitted among humans. This condition requires most countries to implement social distancing policies, even close community activities so that the people feel like being imprisoned for several weeks or even months at home.

The spread of the virus is rapid and massive and it has both positive and negative impacts on human life. The positive impact can be seen in the weather and nature in which various government policies to stop the spread of the virus and the movement of people make gas emissions decrease and the ozone layer improves. Meanwhile, the negative impact can be seen on various aspects of life such as health, mental, environment, economy, education, transportation, food availability or supply, lifestyle, and social life (Khalifa et al., 2021). These positive and negative impacts affect people's habits, especially in Palu City.

The habits of people in Indonesia, especially in Palu City, have significantly changed due to the pandemic. In the health sector, there are changes in people's lifestyles due to the fear of being infected. In the economy, the income of business actors becomes very low, even with no income. In the transportation aspect, there are restrictions on air and land routes. Then, in the education sector, it has an impact on the mental stress of children because of the absence of face-to-face school meetings. Restrictions on human mobility aim to stop the transmission of the virus (Jamaludin et al., 2020). The results of previous studies have showed that the negative social impact of COVID-19 can affect vulnerable people and people who work in different places. Indeed, the social assistance provided can help them get out of the crisis, but to different degrees (Pongutta, Kantamaturapoj, Phakdeesettakun, \& Phonsuk, 2021).

The lifestyle and social life of the people in Palu City are also disrupted. People cannot apply a luxurious lifestyle. Social life is very limited due to social distancing policy and this makes people change their habits including providing food supplies at home due to fear of being infected with the virus. Overall, social aspects of people's lives in this city have changed due to COVID-19. The social interaction of the community is disturbed and there is a suspicion of one another getting infected. COVID-19 has forced the people of this city to accept new habits and it affects the people's social behavior. This pandemic has also changed people's lifestyles in which previously some tend to have extravagant life, now turn to a simple lifestyle.

Indirectly, the pandemic has a positive impact on people's behavior, and then it affects people's social life. On the other hand, the pandemic made the people lack socialization so that the people's lives look more individualistic. The changes in social life due to the social 
restriction policies implemented by the government become a disturbance for the community activities (Lai, Shih, Ko, Tang, \& Hsueh, 2020).

Disruptions in the community activities caused by the spread of COVID-19 cover health, education, public relations, food supply or availability, and work activities (Dwivedi et al., 2020). For example, people are forced to avoid creating crowds when doing their activities, even though they know each other. The government forces people to comply with health protocols during the pandemic and this indirectly forms new habits of the people in Palu City. The new normal appeal can reduce the rate of transmission of the COVID-19 so there is a need for adaptation from the community to stop the spread of the virus as it possibly can last for a long time (Jamaludin et al., 2020).

\section{CONCLUSION}

COVID-19 contributes to changes in aspects of social life and it greatly determines people's activities in daily life. People's behavior changes in which they use face masks, implement social distancing policy, and others to stop the spread of the virus. Thus, it is necessary to adapt to new habits because conditions are uncertain and may last for a long time. This new habit requires the community to live side by side with COVID-19. In other words, people can have activities like before the pandemic in all aspects of life such as health, education, social, and economy by implementing health protocols..

\section{REFERENCES}

Basellini, U., Alburez-Gutierrez, D., Del Fava, E., Fava, E. D., Perrotta, D., Bonetti, M., ... Zagheni, E. (2020). Linking excess mortality to Google mobility data during the COVID19 pandemic in England and Wales. https://doi.org/10.31235/osf.io/75d6m

Brauner, J. M., Mindermann, S., Sharma, M., Johnston, D., Salvatier, J., Gavenčiak, T., ... Kulveit, J. (2021). Inferring the effectiveness of government interventions against COVID-19. Science, 371(6531). https://doi.org/10.1126/science.abd9338

Dwivedi, Y. K., Hughes, D. L., Coombs, C., Constantiou, I., Duan, Y., Edwards, J. S., ... Upadhyay, N. (2020). Impact of COVID-19 pandemic on information management research and practice: Transforming education, work and life. International Journal of Information Management, 55, 102211. https://doi.org/10.1016/j.ijinfomgt.2020.102211

Hanafi, Y., Taufiq, A., Saefi, M., Ikhsan, M. A., Diyana, T. N., Thoriquttyas, T., \& Anam, F. K. (2021). The new identity of Indonesian Islamic boarding schools in the "new normal": The education leadership response to COVID-19. Heliyon, 7(3), e06549. https://doi.org/10.1016/j.heliyon.2021.e06549

Irini, F., Kia, A. N., Shannon, D., Jannusch, T., Murphy, F., \& Sheehan, B. (2021). Associations between mobility patterns and COVID-19 deaths during the pandemic: A network structure and rank propagation modelling approach. Array, 11, 100075. https://doi.org/10.1016/j.array.2021.100075 
Jamaludin, S., Azmir, N. A., Mohamad Ayob, A. F., \& Zainal, N. (2020). COVID-19 exit strategy: Transitioning towards a new normal. Annals of Medicine and Surgery, 59, 165170. https://doi.org/10.1016/j.amsu.2020.09.046

Khalifa, S. A. M., Swilam, M. M., El-Wahed, A. A. A., Du, M., El-Seedi, H. H. R., Kai, G., ... El-Seedi, H. R. (2021). Beyond the Pandemic: COVID-19 Pandemic Changed the Face of Life. International Journal of Environmental Research and Public Health, 18(11), 5645. https://doi.org/10.3390/ijerph18115645

Krammer, S. M. S. (2021). Navigating the New Normal: Which firms have adapted better to the COVID-19 disruption? Technovation, 102368. https://doi.org/10.1016/j.technovation.2021.102368

Lai, C.-C., Shih, T.-P., Ko, W.-C., Tang, H.-J., \& Hsueh, P.-R. (2020). Severe acute respiratory syndrome coronavirus 2 (SARS-CoV-2) and coronavirus disease-2019 (COVID-19): The epidemic and the challenges. International Journal of Antimicrobial Agents, 55(3), 105924. https://doi.org/10.1016/j.ijantimicag.2020.105924

Latief, M. I., Hasbi, \& Amandaria, R. (2021). Collaboration in handling COVID-19 toward people in poverty line: Study case in Makassar. Gaceta Sanitaria, 35, S30-S32. https://doi.org/10.1016/j.gaceta.2020.12.009

Pongutta, S., Kantamaturapoj, K., Phakdeesettakun, K., \& Phonsuk, P. (2021). The social impact of the COVID-19 outbreak on urban slums and the response of civil society organisations: A case study in Bangkok, Thailand. Heliyon, 7(5), e07161. https://doi.org/10.1016/j.heliyon.2021.e07161

Tatem, A. J., Rogers, D. J., \& Hay, S. I. (2006). Global Transport Networks and Infectious Disease Spread. In S. I. Hay, A. Graham, \& D. J. Rogers (Eds.), Advances in Parasitology (pp. 293-343). Academic Press. https://doi.org/10.1016/S0065-308X(05)62009-X

Teherani, A., Martimianakis, T., Stenfors-Hayes, T., Wadhwa, A., \& Varpio, L. (2015). Choosing a Qualitative Research Approach. Journal of Graduate Medical Education, 7(4), 669-670. https://doi.org/10.4300/JGME-D-15-00414.1

Tibbetts, M., Epstein-Shuman, A., Leitao, M., \& Kushlev, K. (2021). A week during COVID19: Online social interactions are associated with greater connection and more stress. Computers in Human Behavior Reports, 100133. https://doi.org/10.1016/j.chbr.2021.100133

Wilson, M. E. (1995). Travel and the emergence of infectious diseases. Emerging Infectious Diseases, 1(2), 39-46. 